\title{
Interaksi Kompetensi Kepribadian Guru dengan Kepuasan Kerja
}

\author{
Sukoyo, Juhji \\ Pengawas Madrasah Kementerian Agama Kota Tangerang Selatan, Banten \\ Universitas Islam Negeri Sultan Maulana Hasanuddin Banten \\ e-mail: juhji@uinbanten.ac.id
}

Submitted: 14-09-2021 Revised : 10-10-2021 Accepted: 19-10-2021

\begin{abstract}
This article aims to analyze and discribe the interaction of the teacher's personality competence with job satisfaction. This article uses the correlational method. A total of 68 madrasa teachers in South Tangerang were used as respondents. Primary data was obtained through the Google Forms platform, which was distributed within two weeks. At the same time, secondary data was obtained from references related to job satisfaction and personality competence. The instrument used in the study was a questionnaire compiled according to a validated Likert scale. Data analysis using a simple regression test. The results showed that there was an interaction between the teacher's personality competence and job satisfaction. The study of both is discussed further. The recommendation of this study is that teachers can improve personality competencies because it is proven to be related to their job satisfaction in madrasas.
\end{abstract}

Keywords: Teacher's personality competence, job satisfaction, madrasab.

\begin{abstract}
Artikel ini bertujuan untuk menganalisis interaksi kompetensi kepribadian guru dengan kepuasan kerja. Artikel ini menggunakan metode korelasional. Sebanyak 68 guru madrasah di Tangerang Selatan dijadikan sebagai responden. Data primer diperoleh melalui platform Google Form yang disebarkan dalam waktu dua minggu. Sedangkan data sekunder diperoleh dari referensi terkait kepuasan kerja dan kompetensi kepribadian. Instrumen yang digunakan dalam penelitian berupa kuesioner yang disusun menurut skala Likert yang telah divalidasi. Analisis data menggunakan uji regresi sederhana. Hasil penelitian menunjukkan adanya interaksi antara kompetensi kepribadian guru dengan kepuasan kerja. Telaah terhadap keduanya dibahas lebih lanjut. Rekomendasi penelitian ini agar para guru dapat meningkatkan kompetensi kepribadian karena terbukti berkaitan dengan kepuasan kerja mereka di madrasah.
\end{abstract}

Keywords: Kompetensi Kepribadian guru, kepuasan kerja, madrasah.

https://doi.org/10.31538/munaddhomah.v2i2.98

How to Cite Sukoyo, Juhji,. (2021). Interaksi Kompetensi Kepribadian Guru dengan Kepuasan Kerja. Munaddhomah: Jurnal Manajemen Pendidikan Islam, Volume (2), 95-102

\section{PENDAHULUAN}

Pendidikan merupakan sebuah proses pendewasaan manusia yang dinamis (Tolchah, 2015), karena tiap penerapan dan tindakan yang diberikan guru harus sesuai dengan visi, misi, dan tujuan pendidikan. Melalui lembaga pendidikan, tujuan yang telah dicanangkan harus dicapai seoptimal mungkin. Merujuk pendapat Calam dan Qurniati (2016), bahwa visi dan misi adalah elemen yang esensial bagi sekolah karena pelaksanaan proses pembelajaran yang dilakuan harus mengedepankan tujuan yang telah diamanatkan oleh para stakeholder. Meskipun demikian, proses penyelenggaraan pendidikan dengan target ketercapaian visi, misi, dan tujuan tidak mudah. Hal ini disebabkan karena dalam pendidikan dibutuhkan elemen sumberdaya yang dapat 
menyokong keterlaksanaan prosesnya, seperti pendidik dan tenaga kependidikan, kurikulum, pembiayaan, sarana dan prasarana pendidikan dimana dalam Undang-Undang Nomor 20 Tahun 2003 dikenal dengan sumber daya pendidikan (Undang-Undang Republik Indonesia Nomor 20, 2003).

Peningkatan kualitas pendidikan merupakan suatu proses yang terintegrasi dengan proses peningkatan sumber daya manusia (Dacholfany, 2017; Hasnadi, 2019). Guru berperan sangat penting dalam proses pencapaian kualitas dan tujuan pendidikan nasional (Surani \& Mifthahudin, 2018) terlebih di era digital (Sutarman et al., 2019). Ini artinya, kemampuan ICT perlu dikembangkan (Supardi et al., 2021). Secara praktis, guru berkontribusi terhadap pembentukan prilaku, sikap, pengetahuan, dan keterampilan para peserta didik baik secara individu maupun secara kelompok. Guru yang merasa mendapatkan kepuasan dalam melaksanakan pekerjanya, tentu mereka dapat bekerja dengan senang hati dan merasa berharga. Kepuasan kerja guru pada dasarnya merupakan fungsi dari harapan sekaligus realisasi terhadap tujuan. Menurut Demirtas (2010), kepuasan kerja adalah keadaan emosional yang positif atau menyenangkan yang dihasilkan dari penghargaan seseorang terhadap pekerjaan atau pengalamannya sendiri. Dengan begitu dapat dipahami bahwa kepuasan kerja guru merupakan seperangkat perasaan terhadap kondisi menyenangkan atau tidaknya pekerjaan mereka di sekolah.

Pada dasarnya, kepuasan kerja merupakan hal yang bersifat individual dimana setiap individu akan memiliki tingkat kepuasan berbeda-beda sesuai dengan sistem nilai-nilai yang berlaku dalam dirinya. Umumnya, beberapa riset mengungkap faktor penting yang berkaitan dengan kepuasan kerja adalah imbalan, seperti gaji, tunjangan (Talachi et al., 2014), insentif, dan penghargaan (Barusman \& Mihdar, 2014). Semua faktor-faktor yang diungkap tersebut memaparkan materi. Penelitian lain mengungkap bahwa gaji bukan merupakan penentu utama bagi ketidakpuasan seseorang. Alasannya karena tempat kelahiran dan umur memainkan peran yang esensial dalam menentukan kepuasan kerja seseorang. Di lain sisi, adanya konflik di tempat kerja, hubungan dengan rekan kerja, serta struktur organisasi dilaporkan Khamlub et al. (2013) sebagai faktor utama yang berhubungan dengan kepuasan kerja. Dengan demikian, kepuasan kerja guru tentunya tidak hanya terkait variabel materi namun ada faktor lain yang belum banyak diungkap dalam penelitian.

Kepuasan kerja guru merupakan sebuah respon terhadap seberapa jauh pekerjaan mereka secara keseluruhan dapat memuaskan kebutuhan hidupnya. Tingkat kepuasan kerja guru dapat diobservasi melalui tingkat disiplin kerja, tanggung jawab, dan keseriusan terhadap pekerjaan yang diamanatkan kepada mereka (Kartiko \& Azzukhrufi, 2019). Permasalahan pokok yang ditemui saat ini, adalah bahwa sebagian guru belum menunjukkan tingkat profesionalitasnya secara baik. Selain itu, kelalaian terhadap tugas dan kewajibannya sebagai pendidik sekaligus pengajar di madrasah juga tak lepas dari pengamatan sehari-hari. Hal ini diduga karena guru merasa kurang puas terhadap pekerjaannya yang dijalaninya. Padahal menurut Hamid (2017), guru yang profesional seharusnya dapat menunjukkan citra yang baik di mata publik. Karena guru yang profesional memiliki kepribadian yang utuh (Jailani, 2014), rasa kemanusiaan (Arifin, 2013), adaptif (Desilawasi \& Amrizal, 2014), dan mampu mendidik, melatih, dan menasehati (Juhji \& Suardi, 2018). Penelitian Hayati dan Caniago (2012) juga menunjukkan kepuasan kerja dan motivasi intrinsik memoderasi hubungan etos kerja Islami pada komitmen organisasi dan prestasi kerja. 
Kompetensi kepribadian guru dipercaya sebagai salah satu variabel yang dapat menentukan keberhasilan belajar peserta didik (Huda, 2017). Ni'mah (2014) menyatakan bahwa kompetensi kepribadian adalah kompetensi utama yang melandasi kompetensi lainnya seperti kompetensi sosial, kopetensi pedagogik, dan kompetensi profesional. Dengan demikian, kompetensi kepribadian guru merupakan kompetensi personal yang menunjukkan kepribadian yang stabil, mantap, arif, berwibawa, dewasa, dan menjadi telada bagi para siswanya. Namun, sebagian guru menunjukkan adanya kompetensi kepribadian yang rendah ditandai dengan sikapnya yang tidak mencerminkan layaknya seorang guru yang dapat digugu dan ditiru. Padahal guru adalah sosok yang patut dijadikan contoh dan teladan yang baik bagi para siswanya karena sikap dan kepribadian yang dimilikinya. Berdasarkan permasalahan tersebut, penelitian ini menganalisa interaksi antara kepuasan kerja dengan kompetensi kepribadian guru.

\section{METODE PENELITIAN}

Metode yang digunakan dalam penelitian ini adalah meode survei. Sebanyak 68 guru madrasah di Tangerang Selatan dijadikan sebagai responden. Data primer diperoleh dari kuesioner yang disebarkan melalui platform Google Form. Sedangkan data sekunder diperoleh dari referensi terkait kepuasan kerja dan kompetensi kepribadian yang bersumber dari buku-buku dan jurnal-jurnal ilmiah. Instrumen yang digunakan dalam penelitian ini adalah kuesioner yang disusun menurut model Skala Likert. Instrumen penelitian divalidasi terlebih dahulu sehingga didapat butir-butir instrumen yang valid dan reliabel. Sebelum dianalisa, data hasil penelitian dilakukan uji prasyarat agar dapat diuji lanjut. Data yang terkumpul, dianalisa dengan menggunakan teknik statistika, baik statistika deskriptif maupun statistika inferensial.

\section{HASIL DAN PEMBAHASAN}

Deskriptif data dalam penelitian ini mencakup nilai mean dan standar deviasi dari kedua variabel penelitian. Data mentah diolah dengan menggunakan metode statistik deskriptif. Hasil Analisa Statistik Deskriptif dapat dilihat pada Tabel 1 berikut ini.

Tabel 1. Statistik Deskriptif Kepuasan Kerja dan Kompetensi Kepribadian

\begin{tabular}{lccc}
\hline \multicolumn{1}{c}{ Variabel } & Mean & Standar Deviasi & Interpretasi \\
\hline Kepuasan Kerja & 4,351 & 3,082 & Tinggi \\
Kompetensi Kepribadian & 3,932 & 3,422 & Sedang \\
\hline
\end{tabular}

Berdasarkan Tabel 1, terlihat bahwavariabel kepuasan kerja responden berada pada kategori tinggi dengan rata-rata 4,351 dan standar deviasi sebesar 3,082. Sementara itu, variabel kompetensi kepribadian berada pada kategori sedang dengan rata-rata 3,932 dan standar deviasi sebesar 3,422. Dengan demikian, hasil penelitian menunjukkan adanya penilaian yang baik terhadap kepuasan kerja guru dibandingkan kompetensi kepribadian. Untuk menganalisis besarnya interaksi antara kepuasan kerja guru dengan kompetensi kepribadian dilakukan uji regresi sederhana melalui bantuan aplikasi SPSS 16.0. Hasil analisis uji regresi dapat dilihat pada Tabel 2 berikut. 
Tabel 2. Analisis Regresi Kepuasan Kerja dan Kompetensi Kepribadian

\begin{tabular}{|c|c|c|c|c|c|}
\hline \multirow[b]{2}{*}{ Model } & \multicolumn{2}{|c|}{$\begin{array}{r}\text { Unstandardized } \\
\text { Coefficients }\end{array}$} & \multirow{2}{*}{$\begin{array}{r}\begin{array}{r}\text { Standardized } \\
\text { Coefficients }\end{array} \\
\text { Beta }\end{array}$} & \multirow[t]{2}{*}{$\mathrm{t}$} & \multirow[t]{2}{*}{ Sig. } \\
\hline & B & Std. Error & & & \\
\hline (Constant) & 35.462 & 5.720 & & 6.200 & .000 \\
\hline Kompetensi Kepribadian Guru & .806 & .048 & .895 & 16.793 & .000 \\
\hline
\end{tabular}

a. Dependent Variable: Kepuasan Kerja

Berdasarkan Tabel 2 di atas, terlihat bahwa arah regresi B sebesar $=0.806$ dan konstanta a sebesar 35,462. Dengan demikian, bentuk kedua hubungan pada kedua variabel dapat digambarkan dengan persamaan regresi $\hat{Y}=35.462+0.806 \mathrm{X}$. Sebelum digunakan untuk keperluan ramalan, persamaan regresi harus memenuhi syarat uji kepentingan (signifikansi) dan uji kelinieran. Untuk mengetahui derajat kepentingan dan kelinieran persamaan regresi, dilakukan uji $\mathrm{F}$ dan hasilnya diketahui bahwa nilai $\mathrm{F}$ hitung lebih besar dari $\mathrm{F}$ tabel pada signifikansi 1 persen. Secara matematis dapat disimbolkan bahwa $F_{\text {hitung }}>F_{\text {Tabel }}(281,199>7.10)$ pada $\alpha=0.01$. Berdasarkan hasil tersebut, dapat dinyatakan bahwa persamaan regresi telah memenuhi persyaratan untuk keperluan ramalan.

Bahwa regresi $\mathrm{X}$ atas $\mathrm{Y}$ sangat signifikan dengan harga $\mathrm{F}_{\text {hitung }}$ tuna cocok hasil perhitungan sebesar 1,437, dengan nilai signifikansi $p=0.145 \geq 0.000$, maka bentuk regresi $\mathrm{Y}$ atas $\mathrm{X}$ adalah liniear. Dengan demikian, dapat disimpulkan bahwa persamaa regresi $\hat{Y}=35.462+0.806 \mathrm{X}$ sangat signifikan dan liniear. Regresi tersebut mengandung arti, bahwa apabila kompetensi kepribadian guru naik satu unit sehingga akan berpengaruh terhadap peningkatan kepuasan kerja sebesar 0.806 unit pada nilai tetap 35.462. Selanjutnya, kekuatan kontribusi variabel X terhadap Y ditunjukkan oleh koefisien korelasi $\mathrm{r}_{\mathrm{y}}$ sebesar $=0.895$, uji kepentingan koefisien korelasi dengan uji $\mathrm{t}$ didapat harga $\mathrm{t}_{\text {hitung }}$ sebesar 16.667. Sedangkan $\mathrm{t}_{\text {tabel }}$ pada $\alpha=0.05, \mathrm{dk}=67$ didapat harga $\mathrm{t}_{\text {tabel }}$ sebesar 1.67 pada signifikansi 0.01 adalah 2.39. Didapati bahwa $t_{\text {hitung }}>t_{\text {tabel }}(16,667>2,39)$, maka dapat disimpulkan hipotesis penelitian yang diajukan bahwa terdapat pengaruh positif kompetensi kepribadian guru terhadap kepuasan kerja teruji kebenarannya. Dengan kata lain, bahwa semakin baik dan berkualitas kompetensi kepribadian yang dimiliki guru maka semakin baik dan tinggi pula kepuasan kerja mereka.

Selanjutnya, dilakukan analisis terhadap koefisien determinasi. Koefisien determinasi merupakan kuadrat dari koefisien korelasi antara variabel $\mathrm{X}$ dengan variabel $\mathrm{Y}$. Koefisien determinasi X dengan Y sebesar $\left(r_{y}\right)^{2}=(0.895)^{2}=0.801$. Ini menunjukkan arti bahwa 80.1 persen varian yang terjadi pada kepuasan kerja dapat dijelaskan oleh kompetensi kepribadian guru melalui persamaan regresi $\hat{Y}=35.462+0.806$ X. Dengan demikian, dapat dinyatakan bahwa kompetensi kepribadian guru memiliki kontribusi yang besar pada peningkatan kepuasan kerja yang ada pada diri guru. Artinya, bahwa seorang guru yang memiliki kepuasan kerja adalah guru yang memiliki kompetensi kepribadian yang baik dan berkualitas. Kompetensi kepribadian guru mencerminkan kepribadian seorang tenaga pendidik yang akan memberikan perubahan positif pada kepuasan kerja mereka sebagai guru di madrasah.

\section{Pembahasan}

Berdasarkan hasil penelitian diperoleh bahwa kepuasan kerja guru madrasah merupakan respon terhadap seberapa jauh pekerjaan mereka secara keseluruhan dapat memuaskan kebutuhan hidup mereka. Kepuasan kerja guru madrasah dapat dipengaruhi oleh sejumlah faktor. 
Salah satu faktor yang berpengaruh terhadap kepuasan kerja guru madrasah adalah kompetensi kepribadian guru. Kompetensi kepribadian sangat menentukan kualitas diri sebagai seorang guru. Karena itu, guru wajib memiliki kompetensi kepribadian yang baik karena ia sebagai teladan bagi peserta didik. Sebagaimana dinyatakan oleh Sopandi (2019) bahwa guru adalah teladan bagi siswa sehingga ia harus memiliki kompetensi kepribadian yang baik. Guru adalah orang yang digugu dan ditiru (Ridla, 2008; Faizin, 2012; Ghofar, 2019). Pernyataan serupa bahwa guru adalah suri teladan yang baik juga disampaikan oleh Sarjana dan Khayati (2016) serta (Amin, 2017). Kepribadian guru memunculkan sosok guru ideal yang idola dan dambaan peserta didik (Oktradiksa, 2012). Dwintari (2017) menyatakan bahwa kompetensi kepribadian yang harus dimiliki guru adalah kompetensi yang sesuai dengan norma agama, hukum, sosial, dan kebudayaan nasional Indonesia, jujur, berakhlak mulia, menjadi teladan, mantap, stabil, dewasa, arif, bijaksana, dan berwibawa. Dengan demikian, guru sebagai teladan bagi siswa membutuhkan kepribadian yang baik, sehingga dapat menjadi suri tauladan bagi siswa-siswa di madrasah.

Pada impelemntasinya sebagai pendidik yang berkewajiban untuk mendidik para peserta didik, guru memiliki sifat dan perilaku berbeda-beda. Sifat, sikap, dan perilaku guru yang dimunculkan saat pembelajaran mencerminkan kualitas kepribadian mereka. Faktor kepribadian guru dapat digunakan dalam memprediksi kepuasan kerja guru secara kontekstual, namun tidak mendukung kepuasan kerja secara teknis. Semakin positif sikap kerja yang ditampilkan maka makin besar pula kepuasan kerja. Dari beberapa penelitian yang telah dilakukan nenunjukkan kepribadian menjadi salah satu faktor penentu kepuasan kerja (Robbins \& Judge, 2013). Gibson et al. (2011) mengatakan kepuasan kerja sangat dipengaruhi oleh kepribadaian, bagian dari kepribadian yang berdampak pada kepuasan kerja yaitu extraversion dan introversion. Penelitian ini sejalan dengan penelitian Linz (2003) yang mengatakan bahwa secara positif sikap terhadap kerja ada hubungan positif dengan kepuasan kerja.

Madrasah merupakan institusi yang dibentuk guna mengembangkan intelektualitas dan kompetensi kecakapan dasar yang mengacu pada norma agama. Madrasah merupakan salah lembaga pendidikan Islam tertua yang berperan ganda. Selain menyiapkan peserta didik dalam penguasaan ilmu pengetahuan dan teknologi, madrasah juga bertanggungjawab dalam pembentukan karakter religious perseta didik dalam mengaruhi kehidupan sosial masyarakat yang heterogen di tengah derasnya arus adaptasi teknologi. Karena itu peserta didik madrasah harus dibekali kemampuan ICT (Supardi et al., 2021). Kriteria kualitas belajar dan lulusan para peserta didiknya berdampak terhadap efektivitas dan keberhasilan madrasah. Sejumlah laporan penelitian melaporkan keberhasilan madrasah dalam mengembangkan kepribadian peserta didik (Noor, 2017; Idris \& Usman, 2019; Astuti \& Danial, 2019; Rouf, 2019; Maarif et al., 2020). Keberhasilan madrasah tentu tidak dapat dilepaskan dari peran serta kepala madrasah sebagai pemimpin di madrasah (Baharun, 2017; Fatoni, 2017; Ruhiyat, 2017; Astuti \& Danial, 2019).

Dengan adanya perasaan kepuasan, seorang guru akan terdorong dalam melaksanakan tugas dengan senang hati dan merasa berharga terhadap sesamanya atau lembaga tempat dimana guru tersebut bekerja. Kepuasan kerja juga mempengaruhi kepuasan kehidupannya. Guru yang tidak mendapat kepuasan kerja akan bersikap negatif dan tidak produktif. Kepuasan kerja yang dimiliki guru akan membuat organisasi menjadi produktif dan pada akhirnya akan membawa kepada kesejahteran bagi para gurunya. Kepuasan kerja guru terhadap pekerjaannya menunjukkan kesesuaian antara harapan yang muncul dan imbalan yang disediakan pekerjaan. Kardam dan Rangnekar (2012) mendefinisikan kepuasan kerja sebagai perasaan emosional seorang karyawan 
terhadap pekerjaannya. Artinya, bahwa kepuasan merupakan fungsi dari harapan sekaligus realisasi. Harapan dan kepuasan terletak di dalam lingkaran pengaruh seseorang sehingga kepuasan seseorang tergantung pada selisih antara apa yang dianggap telah didapatkan dengan apa yang dinginkan. Semakin besar kekurangan dan semakin besar hal penting yang diinginkan, maka semakin besar pula ketidakpuasannya, pun begitu pula sebaliknya.

\section{KESIMPULAN}

Guru yang memiliki kepuasan kerja mampu merasakan dan menikmati pekerjaannya sehingga mereka tidak akan merasa jenuh dan bosan. Selain itu, mereka juga menunjukkan sikap lebih giat dan rajin dalam melakukan kewajibannya dalam proses pembelajaran di madrasah. Seorang guru akan merasa puas dengan adanya kesesuaian antara kemampuan, keterampilan, dan harapannya dengan pekerjaan yang dihadapi. Guru dalam menjalankan tugasnya sebagai seorang tenaga pendidik sangat membutuhkan kepuasan kerja yang timbul dalam diri mereka sehingga kepuasan akan memberikan berbagai dampak positif pada pencapaian visi, misi dan tujuan madrasah. Kepuasan kerja guru terbentuk dari dalam diri sehingga adanya kepribadian yang baik berdampak pada kesadaran diri guru untuk melaksanakan tugas dan tanggung jawabnya sebagai seorang tenaga pendidik. Guru yang memiliki kepribadian baik dapat terlihat dari sikap dan perilaku yang ditampilkannya dan dapat menimbulkan kepuasan dalam bekerja. Tanpa adanya kepribadian yang baik maka guru akan memiliki kualitas kepuasan yang rendah.

\section{REFERENSI}

Amin, M. (2017). Peran Guru Dalam Menanamkan Nilai Kejujuran Pada Lembaga Pendidikan. TADBIR: Jurnal Studi Manajemen Pendidikan, 1(1), 105-124.

Arifin, Z. (2013). Menjadi guru profesional (isu dan tantangan masa depan). Edutech, 13(1), 132 155.

Astuti, A., \& Danial, D. (2019). Kepemimpinan Kepala Madrasah dalam Membangun Budaya Madrasah yang Kondusif di Madrasah Aliyah Negeri. El-Idare: Jurnal Manajemen Pendidikan Islam, 5(1), 31-45.

Baharun, H. (2017). Peningkatan kompetensi guru melalui sistem kepemimpinan kepala madrasah. At-Tajdid: Jurnal Ilmu Tarbiyah, 6(1), 1-26.

Barusman, A. R. P., \& Mihdar, F. (2014). The effect of job satisfaction and organizational justice on organizational citizenship behavior with organization commitment as the moderator. International Journal of Humanities and Social Science, 4(9), 118-126.

Calam, A., \& Qurniati, A. (2016). Merumuskan Visi dan Misi Lembaga Pendidikan. Jurnal Saintikom, 15(1), 53-68.

Dacholfany, M. I. (2017). Inisiasi Strategi Manajemen Lembaga Pendidikan Islam Dalam Meningkatkan Mutu Sumber Daya Manusia Islami Di Indonesia Dalam Menghadapi Era Globalisasi. At-Tajdid: Jumal Pendidikan Dan Pemikiran Islam, 1(01), 1-13.

Demirtas, Z. (2010). Teachers' job satisfaction levels. Procedia - Social and Behavioral Sciences, 9, 1069-1073. https://doi.org/10.1016/j.sbspro.2010.12.287

Desilawasi, D., \& Amrizal, A. (2014). Guru Profesional Di Era Global. Jurnal Pengabdian Kepada Masyarakat, 20(77). 
Dwintari, J. W. (2017). Kompetensi kepribadian guru dalam pembelajaran pendidikan kewarganegaraan berbasis penguatan pendidikan karakter. Jurnal Pendidikan Kewarganegaraan, 7(2), 51-57.

Faizin, M. (2012). Peran manajemen qalbu bagi guru. Tarbawi, 1(1), 15-38.

Fatoni, M. (2017). Peran Kepala Madrasah Dalam Meningkatkan Mutu Guru Di MTs Nurul Falah Talok Kresek Kabupaten Tangerang. Tarbawi: Jurnal Keilmuan Manajemen Pendidikan, 3(02), 168-182.

Ghofar, A. (2019). Guru: Digugu dan Ditiru. Al-Misbah (Jurnal Islamic Studies), 5(1), 1-14.

Gibson, J., Ivancevich, J., \& Konopaske, R. (2011). Organizations: Behavior, Structure, Processes. McGraw-Hill Higher Education.

Hamid, A. (2017). Guru Profesional. Al-Falab: Jurnal Ilmiah Keislaman Dan Kemasyarakatan, 17(2), 274-285.

Hasnadi, H. (2019). Perencanaan Sumber Daya Manusia Pendidikan. Bidayah: Studi Ilmu-Imu Keislaman, 10(2), 141-148.

Hayati, K., \& Caniago, I. (2012). Islamic Work Ethic: The Role of Intrinsic Motivation, Job Satisfaction, Organizational Commitment and Job Performance. Procedia-Social and Behavioral Sciences, 65, 1102-1106.

Huda, M. (2017). Kompetensi kepribadian guru dan motivasi belajar siswa. Jurnal Penelitian, 11(2), 237-266.

Idris, D. M., \& Usman, U. (2019). Peranan Pendidikan Akhlak dalam Mengembangkan Kepribadian Peserta Didik di Madrasah Aliyah Negeri 1 Parepare. Al-Musannif, 1(2), $77-$ 95.

Jailani, M. S. (2014). Guru profesional dan tantangan dunia pendidikan. Al-Ta Lim Journal, 21(1), $1-9$.

Juhji, J., \& Suardi, A. (2018). Profesi Guru Dalam Mengembangkan Kemampuan Berpikir Kritis Peserta Didik Di Era Globalisasi. Geneologi PAI: Jurnal Pendidikan Agama Islam, 5(1), $16-$ 24.

Kardam, B. L., \& Rangnekar, S. (2012). Job satisfaction: Investigating the role of experience \& education. Researchers World, 3(4), 16.

Kartiko, A., \& Azzukhrufi, jaya R. (2019). Pengaruh Budaya Organisasi Dan Kompensasi Terhadap Kinerja Pendidik Di Madrasah Aliyah Nahdlatul Ulama Mazro'atul Ulum Paciran. Nidhomul Haq: Jurnal Manajemen Pendidikan Islam, 4(2), 207-226. https://doi.org/10.31538/ndh.v4i2.351

Khamlub, S., Harun-Or-Rashid, M. D., Sarker, M. A. B., Hirosawa, T., Outavong, P., \& Sakamoto, J. (2013). Job satisfaction of health-care workers at health centers in Vientiane Capital and Bolikhamsai Province, Lao PDR. Nagoya Journal of Medical Science, 75(3-4), 233.

Linz, S. J. (2003). Job satisfaction among Russian workers. International Journal of Manpower, 1-34.

Maarif, M. A., Wardi, M., \& Amartika, S. (2020). The Implementation Strategy of Religious Culture in Madrasah. Tarbawi: Jurnal Keilmuan Manajemen Pendidikan, 6(02), 163-174.

Ni'mah, K. (2014). Konsep Kompetensi Kepribadian Guru PAI. Jurnal Pendidikan Agama Islam, 11(1), 79-94.

Noor, W. (2017). Mengintegrasikan manajemen sumber daya manusia di madrasah. Tarbawi: Jurnal Keilmuan Manajemen Pendidikan, 3(02), 153-167.

Oktradiksa, A. (2012). Pengembangan kualitas kepribadian guru. Nadwa: Jurnal Pendidikan Islam, 6(2), 231-248. 
Ridla, M. R. (2008). Profesionalitas Guru Pendidikan Agama Islam dalam Proses Pembelajaran. TADRIS: Jurnal Pendidikan Islam, 3(1).

Robbins, S. P., \& Judge, T. A. (2013). Organizational behavior (4th ed.). Pearson Education.

Rouf, A. (2019). Kepemimpinan kepala madrasah dalam meningkatkan etos kerja guru pada mts pondok besar roudlotul mubtadiin balekambang nalumsari jepara jawa tengah. Tarbawi: Jurnal Keilmuan Manajemen Pendidikan, 5(01), 97-114.

Ruhiyat, M. Y. (2017). Pengaruh Kepemimpinan Kepala Madrasah dan Supervisi Pengawas Madrasah terhadap Kinerja Guru untuk Mewujudkan Mutu Pendidikan di Madrasah. Jurnal Pendidikan Universitas Garut, 11(01), 26-37.

Sopandi, A. (2019). Pengaruh kompetensi profesional dan kompetensi kepribadian terhadap kinerja guru. Scientific Journal of Reflection: Economic, Accounting, Management and Business, 2(2), 121-130.

Supardi, S., Juhji, J., Azkiyah, I., Muqdamien, B., Ansori, A., Kurniawan, I., \& Sari, A. F. (2021). The ICT basic skills: Contribution to student social media utilization activities. International Journal of Evaluation and Research in Education (IJERE), 10(1), 222-229.

Surani, D., \& Mifthahudin, M. (2018). Kompetensi Guru dan Motivasi Mengajar Guru Berpengaruh terhadap Efektivitas Pembelajaran di SMK Negeri 3 Kota Serang. Tarbawi: Jurnal Keilmuan Manajemen Pendidikan, 4(02), 149-158. https://doi.org/doi:10.32678/tarbawi.v4i02.1227

Sutarman, A., Wardipa, I. G. P., \& Mahri, M. (2019). Penguatan Peran Guru di Era Digital Melalui Program Pembelajaran Inspiratif. Tarbawi: Jurnal Keilmuan Manajemen Pendidikan, 5(02), 229-238. https://doi.org/doi:10.32678/tarbawi.v5i02.2097

Talachi, R. K., Gorji, M. B., \& Boerhannoeddin, A. B. (2014). An Investigation of the Role of Job Satisfaction in Employees' Organizational Citizenship Behavior. Collegium Antropologicum, 38(2), 429-436.

Tolchah, H. M. (2015). Dinamika Pendidikan Islam Pasca Orde Baru: Pendidikan. LKIS PELANGI AKSARA.

Undang-Undang Republik Indonesia Nomor 20. (2003). Undang-Undang Republik Indonesia Nomor 20 Tahun 2003 Tentang Sistem Pendidikan Nasional. Pemerintah Republik Indonesia. 